\title{
PERAN GURU DALAM PENGEMBANGAN KURIKULUM
}

\author{
Rikha Rahmiyati Dhani, M. Pd \\ Dosen Prodi Adm. Pendidikan STKIP Budidaya Binjai
}

\begin{abstract}
ABSTRAK
Kurikulum dalam suatu sistem pendidikan merupakan komponen yang amat penting. Kurikulum juga merupakan wahana belajar-mengajar yang dinamis sehingga perlu dinilai dan dikembangkan secara terus-menerus dan berkelanjutan sesuai dengan perkembangan yang ada dalam masyarakat. Guru bertugas melaksanakan pengajaran yang sebaik-baiknya, maka dengan hal itu guru juga bertanggung jawab melaksanakan, membina, dan mengembangkan kurikulum sekolahnya. Guru yang baik harus mampu membuat program belajar mengajar yang baik serta menilai dan melakukan pengayaan terhadap materi kurikulum yang telah digariskan.
\end{abstract}

Kata Kunci: Peran Guru, Pengembangan Kurikulum

\section{PENDAHULUAN}

Salah satu komponen penting dari sistem pendidikan adalah kurikulum. Kurikulum merupakan salah satu alat untuk mencapai tujuan pendidikan, sekaligus merupakan pedoman dalam pelaksanaan pembelajaran pada semua jenis dan jenjang pendidikan. Kurikulum harus sesuai dengan falsafah dan dasar negara, yaitu Pancasila dan UUD 1945 yang menggambarkan pandangan hidup suatu bangsa. Tujuan dan pola kehidupan suatu negara banyak ditentukan oleh sistem kurikulum yang digunakannya, mulai dari kurikulum Taman kanak-kanak sampai dengan kurikulum peguruan tinggi. Jika terjadi perubahan perubahan sistem ketatanegaraan, maka dapat berakibat pada perubahan sistem pendidikan, bahkan terhadap sistem kurikulum yang berlaku.

Kurikulum memegang kedudukan kunci dalam pendidikan, sebab berkaitan dengan arah, isi dan proses pendidikan yang pada akhirnya menentukan macam dan kualifikasi lulusan suatu lembaga pendidikan. Dalam suatu lembaga pendidikan, salah satu tokoh yang memiliki peranan yang begitu penting dalam pengembangan kurikulum adalah guru.

Guru merupakan ujung tombak keberhasilan pendidikan yang terlibat langsung dalam mengembangkan, memantau dan melaksanakan kurikulum sehingga pembelajaran dapat berjalan dengan lancar dan dapat mencapai tujuan yang diharapkan. Meskipun ilmu pengetahuan mengalami perkembangan yang cukup pesat, tidak berarti menyurutkan peranan guru. Bahkan hasil-hasil teknologi tersebut akan menambah beban tugas dan tanggung jawab guru. Oleh karenanya, guru sebagai pelaku utama pendidikan diwajibkan memenuhi kewajibannya sebagai pendidik profesional dan tentu saja sebagai pengembang kurikulum.

$\begin{array}{crrr} & \text { Pengembangan } & \text { kurikulum adalah } \\ \text { proses } & \text { perencanaan } & \text { kurikulum agar }\end{array}$ menghasilkan rencana kurikulum yang luas dan spesifik. Proses ini berhubungan dengan seleksi dan pengorganisasian berbagai komponen situasi belajar mengajar antara lain penetapan jadwal pengorganisasian kurikulum dan spesifikasi tujuan yang disarankan, mata pelajaran, kegiatan, sumber, dan alat pengukur 
pengembang kurikulum yang mengacu pada kreasi sumber unit, rencana unit, dan garis pelajaran kurikulum lainnya untuk memudahkan proses belajar mengajar.

\section{KAJIAN TEORI \\ Konsep Guru}

Ada beragam julukan yang diberikan kepada sosok guru. Salah satu yang paling terkenal adalah "Pahlawan Tanpa Tanda Jasa". Julukan ini mengindikasikan betapa besarnya peran dan jasa yang dilakukan guru sehingga guru disebut sebagai pahlawan (Naim, 2009:1). Namun, penghargaan terhadap guru ternyata tidak sebanding dengan besarnya jasa yang telah diberikan. Guru adalah sosok yang rela mencurahkan sebagian besar waktunya untuk mengajar dan mendidik siswa, sementara penghargaan dari sisi material misalnya, sangat jauh dari harapan. Hal itulah, tampaknya yang menjadi salah satu alasan mengapa guru disebut sebagai pahlawan tanpa tanda jasa.

Guru atau pendidik merupakan sosok yang harus mempunyai banyak ilmu, mau mengamalkan dengan sungguh-sungguh ilmunya tersebut dalam proses pembelajaran dalam makna yang luas, toleran, dan senantiasa berusaha menjadikan siswanya memiliki kehidupan yang lebih baik.

Secara prinsip, mereka yang disebut sebagai guru bukan hanya mereka yang memiliki kualifikasi keguruan secara formal yang diperoleh lewat jenjang pendidikan di perguruan tinggi saja, tetapi yang terpenting adalah mereka yang mempunyai kompetensi keilmuan tertentu dan dapat menjadikan orang lain pandai dalam matra kognitif, afektif dan psikomotorik. Matra kognitif menjadikan siswa cerdas dalam aspek intelektualnya, matra afektif menjadikan siswa mempunyai sikap dan perilaku yang sopan, dan matra psikomotorik menjadikan siswa terampil dalam melaksanakan aktivitas secara efektif dan efisien serta tepat guna, (Naim, 2009:4).

Di sinilah letak pentingnya peranan seorang guru. Sehingga bukan hal yang terlalu berlebihan jika ada penilaian bahwa berhasil atau tidaknya proses pendidikan tergantung kepada peranan guru. Walaupun peranannya sangat menentukan, namun harus disadari bahwasanya guru bukan satu-satunya penentu keberhasilan atau kegagalan pembelajaran. Sebab, keberhasilan atau kegagalan pembelajaran dipengaruhi oleh beragam faktor yang saling berkaitan antara satu dengan yang lainnya.

Dalam konsep pendidikan tradisional, posisi guru begitu terhormat. Guru diposisikan sebagai orang yang 'alim, wara', shalih, dan sebagai uswah sehingga guru dituntut juga beramal saleh sebagai aktualisasi dari keilmuan yang dimilikinya (Naim, 2009:5). Oleh karena itu, wajar jika mereka diposisikan sebagai orang-orang penting dan mempunyai pengaruh besar pada masanya, dan seolah-olah memagang kunci keselamatan rohani dalam masyarakat.

Seiring perkembangan zaman, posisi dan peran guru juga mengalami perubahan. Otoritas guru semakin menyusut di tengah gerusan perubahan yang kian kompleks. Guru kini menghadapi tantangan besar yang semakin hari semakin berat. Hal ini menuntut seorang guru untuk senantiasa melakukan berbagai upaya dalam meningkatkan kualitas pribadi maupun sosialnya. Tanpa usaha semacam ini, posisi dan peranan guru akan semakin terkikis.

Jika seorang guru senantiasa memiliki spirit yang kuat untuk meningkatkan kualitas pribadi maupun sosialnya, maka keberhasilan dalam menjalankan tugasnya akan lebih cepat untuk tercapai, yaitu mampu melahirkan para siswa yang memiliki budi pekerti luhur, memiliki karakter sosial dan profesional 
sebagaimana yang menjadi tujuan fundamental dari pendidikan.

\section{Konsep Kurikulum}

Menurut Soetjipto dan Kosasi (2011:147), kurikulum dalam suatu sistem pendidikan merupakan komponen yang amat penting. Dikatakan demikian karena kurikulum merupakan panutan dalam penyelenggaraan proses belajar-mengajar disekolah. Kualitas keluaran proses pendidikan antara lain ditentukan oleh kurikulum dan efektivitas pelaksanaannya. Kurikulum itu harus sesuai dengan filsafat dan cita-cita bangsa, perkembangan siswa, perkembangan ilmu dan teknologi, serta kemajuan dan tuntutan masyarakat terhadap kualitas lulusan lembaga pendidikan itu.

Kurikulum dapat diartikan secara sempit atau luas. Dalam pengertian sempit, kurikulum diartikan sebagai sejumlah mata pelajaran yang diberikan disekolah; sedangkan dalam pengertian luas kurikulum adalah semua pengalaman belajar yang diberikan sekolah kepada siswa, selama mereka mengikuti pendidikan di sekolah itu. Dengan pengertian luas ini berarti, segala usaha sekolah untuk memberikan pengalaman belajar kepada siswa dalam usaha menghasilkan lulusan baik secara kualitatif maupun kuantitatif.

Kurikulum juga merupakan wahana belajar-mengajar yang dinamis sehingga perlu dinilai dan dikembangkan secara terus-menerus dan berkelanjutan sesuai dengan perkembangan yang ada dalam masyarakat. Agar pengembangan kurikulum dapat berhasil sesuai dengan yang diinginkan, maka dalam pengembangan kurikulum diperlukan landasanlandasan pengembangan kurikulum.

\section{PEMBAHASAN}

\section{Guru dan Pengembangan Kurikulum}

Pembuatan keputusan dalam pembinaan kurikulum bukan saja menjadi tanggung jawab para perencana kurikulum, akan tetapi juga menjadi tanggung jawab para guru disekolah. Para perencana kurikulum perlu membuat keputusan yang tepat, rasional dan sistematis. Pembuatan keputusan itu tidak dapat dibuat secara acak-acakan, melainkan harus berdasarkan informasi dan data yang objektif. Untuk itu terlebih dahulu perlu diadakan evaluasi yang objektif terhadap kurikulum yang sedang berlaku.

Thorndika dan Hagen dalam Hamalik (2002:20) menjelaskan evaluasi memegang peranan yang penting dalam membuat keputusan-keputusan kurikuler, sehingga dapat diketahui hasil-hasil kurikulum yang telah dilaksanakan, apakah kelemahan dan kekuatannya dan selanjutnya dapat dipikirkan mengenai perbaikan-perbaikan yang diperlukan.

Demikian pula guru harus mampu membuat aneka macam keputusan dalam pembinaan kurikulum. Pada dasarnya betapa pun baiknya suatu kurikulum, berhasil atau tidaknya akan sangat bergantung kepada tindakan-tindakan guru disekolah dalam melaksanakan kurikulum itu.

Hamalik (2002:21) menjelaskan kriteria-kriteria kurikulum dapat digunakan dalam dua fungsi, yakni untuk merencanakan kurikulum pendidikan guru dan untuk menilai kurikulum pendidikan guru. Jika kriteriakriteria itu digunakan untuk merencanakan kurikulum, maka dapat dianggap sebagai petunjuk-petunjuk elementer, yang merupakan patokan dalam menyusun komponenkomponen kurikulum yang diperlukan.

Kurikulum meliputi komponenkomponen, yaitu tujuan pendidikan, tujuan instuksional, alat dan metode instruksional, pemilihan dan pembimbingan siswa materi program, evaluasi dan staf pelaksanaan 
kurikulum. Semua komponen itu tampaknya harus dipertimbangkan dalam penyusunan kurikulum secara keseluruhan.

Jika kriteria-kriteria kurikulum telah dirumuskan dan kita gunakan untuk menilai kurikulum maka kiranya akan lebih cepat, karena kriteria itu memuat tentang perincian hal-hal yang perlu dinilai dan sekaligus bagaimana cara menilainya. Uraian yang singkat dan jelas lebih memudahkan seorang evaluator kurikulum melakukan tugasnya. Dalam konteks ini kita perlu berhati-hati, sebab dalam menilai kurikulum pendidikan guru, kita tidak cukup menilai setiap komponen secara terlepas-lepas, seolah-olah antara satu komponen dengan komponen lainnya tidak ada hubungannya.

Aspek lain yang perlu juga dipertanyakan ialah apa peranan guru dalam hubungannya dengan pembinaan kurikulum atau dalam hubungannya dengan pembuatan kurikulum pendidikan guru. Dengan asumsi bahwa guru (lembaga pendidikan guru) bertugas melaksanakan pengajaran yang sebaik-baiknya, maka dengan hal itu guru juga bertanggung jawab melaksanakan, membina, dan mengembangkan kurikulum sekolahnya.

Maka dari itu, guru yang baik harus mampu membuat program belajar mengajar yang baik serta menilai dan melakukan pengayaan terhadap materi kurikulum yang telah digariskan. Diasumsikan bahwa guru yang baik adalah guru yang mampu menciptakan pengajaran yang baik. Pengajaran yang baik ialah pengajaran yang berhasil melalui proses pengajaran yang efektif, (Hamalik, 2002:24)

Peran guru dalam pengembangan kurikulum diwujudkan dalam bentuk-bentuk kegiatan berikut:

1. Merumuskan tujuan khusus pengajaran berdasarkan tujuan-tujuan kurikulum diatasnya dan karakteristik pebelajar, mata pelajaran/bidang studi, dan karakteristik situasi kondisi sekolah/kelas.

2. Merencanakan kegiatan pembelajaran yang dapat secara efektif membantu pebelajara mencapai tujuan yang ditetapkan.

3. Menerapkan rencana/program pembelajaran yang dirumuskan dalam situasi pembelajaran yang nyata.

4. Mengevalusi hasil dan proses belajar pada pebelajar.

5. Mengevaluasi interaksi antara komponenkomponen kurikulum yang diimplementasikan.

Lima kegitan tersebut merupakan peran dalam pengembangan kurikulum yang bersifat sentralisasi. Sedangkan dalam pengembangan kurikulum yang bersifat desentralisasi, peran guru lebih besar, yakni mencakup pengembangan keseluruhan komponenkomponen kurikulum dalam perencanaan, mengimplementasikan kurikulum yang dikembangkan, mengevaluasi implementasi kurikulum, dan merevisi komponen-komponen kurikulum yang kurang memadai, (Dimyati dan Mudjiono, 2013:288).

\section{Model-Model Kurikulum}

Untuk melakukan pengembangan kurikulum ada berbagai model pengembangan kurikulum yang dapat dijadikan acuan atau diterapkan sepenuhnya. Berikut ini akan diuraikan tentang beberapa model pengembangan kurikulum, diantaranya, (Dimyati dan Mudjiono, 2013:280):

1. Model Administratif (Line-Staff)

Model pengembangan kurikulum ini berdasarkan pada cara kerja atasan-bawahan (top-down) yang dipandang efektif dalam pelaksanaan perubahan, termasuk perubahan kurikulum. Model administrasi/garis-komando memiliki langkah-langkah berikut ini:

1) Administrator pendidikan/ top administrative officers (pemimpin) membenuk komisi pengarah. 
2) Komisi pengarah (steering comittee) bertugas merumuskan rencana umum, mengembangkan prinsip-prinsip sebagai pedoman, dan menyiapkan suatu pernyataan filosofi dan tujuantujuan untuk seluruh wilayah.

3) Membentuk komisi kerja pengembangan kurikulum yang bertugas mengembangkan kurikulum secara operasional mencakup keseluruh komponen kurikulum dengan mempertimbangkan landasan dan prinsip-prinsip pengembangan kurikulum.

4) Komisi pengarah memeriksa hasil kerja dari komisi kerj dan menyempurnakan bagian-bagian tertentu bila dianggap perlu. Karena pengembangan kurikulum model administratif ini berdasarkan konsep, inisiatif, dan arahan dari atas ke bawh, maka akan memerlukan waktu bertahun-tahun agar dapat berjalan dengan baik. Hal ini disebabkan adanya tuntutan untuk mempersiapkan para pelaksana kurikulum tersebut.

\section{Model Grass-Roots}

Model pengembangan kurikulum ini merupakan kebalikan dari model administratif dilihat dari sumber inisiatif dan upaya pengembangan kurikulum. Bila model administratif semua inisiatif dan upaya pengembangan kurikulum dari atas, maka model rakyat biasa (grass-roots) semua inisiatif dan upaya pengembangan kurikulum dari bawah.

\section{Model Beauchamp}

Pengembangan kurikulum dengan menggunakan model Beauchamp memiliki lima bagian pembuatan keputusan. Lima tahap pembuatan keputusan tersebut adalah:

1) Memutuskan arena pengembangan kurikulum, suatu keputusan yang menjabarkan ruang lingkup upaya pengembangan.

2) Memilih dan melibatkan personalia pengembangan kurikulum, suatu keputusan yang menetapkan personalia upaya pengembangan kurikulum.

3) Pengorganisasian dan prosedur pengembangan kurikulum.

4) Implementasi kurikulum, yakni kegiatan untuk menerapkan kurikulum seperti yang sudah diputuskan dalam ruang lingkup pengembangan kurikulum.

5) Evaluasi kurikulum.

4. Model Arah Terbalik Taba (Taba's Inverted Model)

Sesuai dengan namanya, model pengembangan kurikulum ini terbalik dari yang lazim dilaksanakan, yakni dari biasanya dilakukan secara deduktif dibalik menjadi induktif.

5. Model Rogers

Dimyati dan Mudjiono (2013:285) menjelaskan berdasarkan pandangan tentang manusia, maka Rogers mengemukakan model pengembangan kurikulum yang disebut dengan Model Relasi Interpesonal Roger (Rogers Interpersonal Relation Model). Rogers lebih mementingkan kegiatan pengembangan kurikulum daripada rancangan pengembangan kurikulum tertulis, yakni melalui aktivitas dan interaksi dalam pengalaman kelompok intensif yang terpilih.

\section{KESIMPULAN}

Guru atau pendidik merupakan sosok yang harus mempunyai banyak ilmu, mau mengamalkan dengan sungguh-sungguh ilmunya tersebut dalam proses pembelajaran dalam makna yang luas, toleran, dan senantiasa berusaha menjadikan siswanya memiliki kehidupan yang lebih baik. Kurikulum dapat diartikan secara sempit atau luas. Dalam 
pengertian sempit, kurikulum diartikan sebagai sejumlah mata pelajaran yang diberikan disekolah; sedangkan dalam pengertian luas kurikulum adalah semua pengalaman belajar yang diberikan sekolah kepada siswa, selama mereka mengikuti pendidikan di sekolah itu. Dengan pengertian luas ini berarti, segala usaha sekolah untuk memberikan pengalaman belajar kepada siswa dalam usaha menghasilkan lulusan baik secara kualitatif maupun kuantitatif. Model-model Kurikulum meliputi:

1. Model Administratif (Line-Staff)

2. Model Grass-Roots

3. Model Beauchamp

4. Model Arah Terbalik Taba' (Taba's Inverted Model)

5. Model Rogers

\section{DAFTAR PUSTAKA}

Dimyati dan Mudjiono, (2013). Belajar dan Pembelajaran. Jakarta: Rineka Cipta

Hamalik, O. (2002). Pendidikan Guru Berdasarkan Pendekatan Kompetensi. Jakarta: Bumi Aksara

Naim, N. (2009). Menjadi Guru Inspiratif Memberdayakan dan Mengubah Jalan Hidup Siswa. Yogyakarta: Pustaka Belajar

Soetjipto dan Kosasi, R. (2011). Profesi Keguruan. Jakarta: Rineka Cipta 